\title{
AGE OF THE YOUNGER LAXÁ LAVA AND LAKE MÝVATN, NORTHERN ICELAND, DETERMINED BY AMS RADIOCARBON DATING
}

\section{Ulf Hauptfleisch}

Mývatn Research Station, Skútustaðir, IS-660 Mývatn, Iceland. Also: University of Iceland, Faculty of Earth Sciences, Sturlugata 7, IS-101 Reykjavík, Iceland. Corresponding author. Email: ulh2@hi.is.

Árni Einarsson

Mývatn Research Station, Skútustaðir, IS-660 Mývatn, Iceland. Also: University of Iceland, Institute of Life and Environmental Sciences, Sturlugata 7, IS-101 Reykjavík, Iceland.

\begin{abstract}
Lake Mývatn and several smaller lakes in northern Iceland were formed by the large Holocene lava flow of the Younger Laxá Lava (YLL). The age of the YLL was estimated by tephrochronology at 1800-2300 BP (Thorarinsson 1951). Conventional radiocarbon dating of charred vegetation beneath the YLL (Thorarinsson 1964) yielded uncalibrated ages of $1940 \pm 270{ }^{14} \mathrm{C}$ yr BP (Yale), $2110 \pm 140{ }^{14} \mathrm{C}$ yr BP (Copenhagen), and $1990 \pm 50{ }^{14} \mathrm{C}$ yr BP (Winnipeg). Ongoing paleolimnological research at Lake Mývatn requires a more precise age estimation of the YLL. Charcoal samples from beneath the YLL were collected at Presthvammur in 2007 and analyzed by accelerator mass spectrometry (AMS) ${ }^{14} \mathrm{C}$ measurements. The reliability of the conventional ${ }^{14} \mathrm{C}$ ages of the samples Yale, Copenhagen, and Winnipeg was re-evaluated, applying criteria from Pettit et al. (2003) and Graf (2009). The result of AMS ${ }^{14} \mathrm{C}$ measurement (2170 \pm 38 cal yr BP) underpins the local tephrochronology and provides a reliable age of the YLL and Lake Mývatn.
\end{abstract}

\section{INTRODUCTION}

The age of volcanic deposits can be estimated by radiocarbon dating of organic material from the contact between the volcanic material and the underlying, buried paleosol. In Iceland, a number of Holocene lava flows have been successfully radiocarbon dated from vegetation charred by contact with the lava (e.g. Sæmundsson 1962, 1966; Kjartansson 1964, 1966, 1973; Jónsson 1971, 1977, 1983; Jakobsson 1976; Jóhannesson and Einarsson 1988; Einarsson et al. 1991; Sinton et al. 2005). Several lava flows of the Mauna Loa Volcano in Hawaii have been dated in a similar way (Buchanan-Banks et al. 1989) and ${ }^{14} \mathrm{C}$ dating of buried soil, peat, and sediment in tephra interbeds yielded a reconstruction of Holocene volcanic activity in Kamtchatka, Siberia (Braitseva et al. 1993). Madeira et al. (1995) ${ }^{14} \mathrm{C}$ dated wood, charcoal, peat, and soil from paleosols, buried by pumice and pyroclastic flows, to establish a chronostratigraphical model for the Caldeira formation on Faial Island, Azores. Furthermore, the correspondence of historical records of volcanic activity with the products of single, major volcanic eruptions in Kyushu, Japan, was demonstrated by Okuno et al. (1998) by ${ }^{14} \mathrm{C}$ dating soil and charcoal beneath tephra layers.

The 2 Laxá lavas, the Older Laxá Lava (OLL) and the Younger Laxá Lava (YLL), comprise the largest Late Holocene lava flows in the northern volcanic zone of Iceland (Table 1; Thorarinsson 1951; Jóhannesson and Sæmundsson 1998, 2009).

Table 1 Area and volume of the Older Laxá Lava (OLL) and the Younger Laxá Lava (YLL).

\begin{tabular}{llll}
\hline Name & $\begin{array}{l}\text { Area } \\
\left(\mathrm{km}^{2}\right)\end{array}$ & $\begin{array}{l}\text { Volume } \\
\left(\mathrm{km}^{3}\right)\end{array}$ & Reference \\
\hline YLL & 220 & 2.5 & Thorarinsson 1979 \\
OLL & 300 & 4 & Thorarinsson 1979 \\
& 385 & 8 & Hjartarson 2011 \\
\hline
\end{tabular}

The YLL emanated from a 8.5-km-long N-S trending fissure in the eastern part of the Lake Mývatn district (Figure 1). The low-viscosity basaltic lava poured towards the west into a large but shallow depression created by the Pleistocene glacier erosion and postglacial tectonic subsidence. It flowed 
into and destroyed a preexisting lake (Proto-Mývatn), formed the basin for a new one, the recent Lake Mývatn, and made its way north through the Laxárdalur Valley to the northern coastal waters of Iceland (Figure 1; Thorarinsson 1951; Einarsson 1982; Sæmundsson 1991).

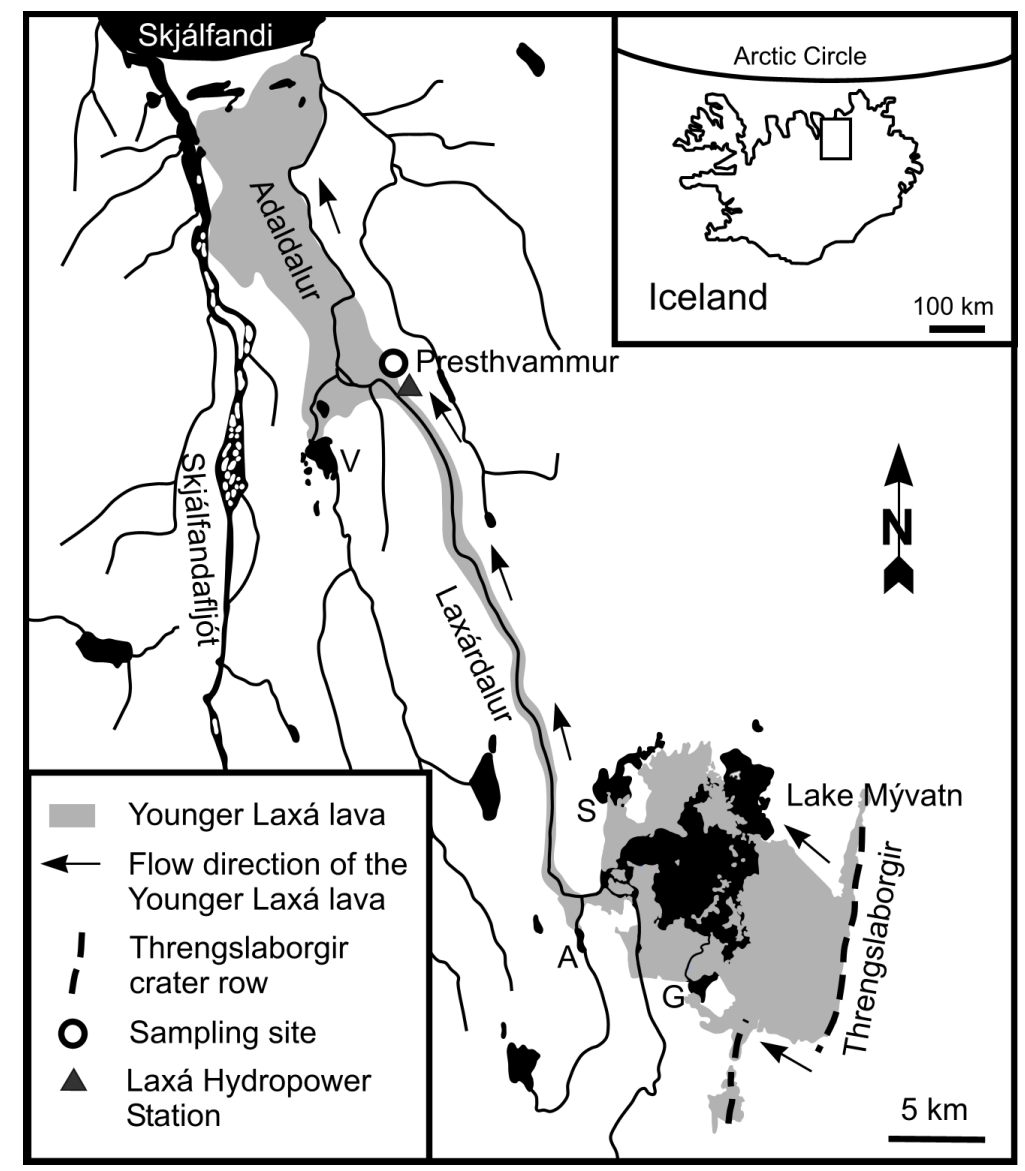

Figure 1 Lake Mývatn and Laxárdalur Valley with the Younger Laxá Lava (YLL); the lakes Sandvatn (S), Arnarvatn (A), Grænavatn (G), and Vestmannsvatn (V); the sampling site of Presthvammur in Aðaldalur Valley; and the Threngslaborgir crater row.

Interactions between the basaltic lava and wet lake sediment caused intensive steam eruptions, creating a myriad of rootless vents (pseudocraters) that now dominate the landscape around Lake Mývatn (Figure 2 upper). Temporary lava pools covering wet sediments led to the creation of lava pillars that also characterize the Lake Mývatn scenery (Figure 2 lower). The YLL dammed 4 other lakes on its way towards the sea (Sandvatn, Arnarvatn, Grænavatn, and Vestmannsvatn, see Figure 1). The YLL covers about $220 \mathrm{~km}^{2}$ (Thorarinsson 1979), making it second only to the OLL that followed a similar course through the Laxárdalur Valley at about 3800 BP.

During the early years of his pioneering work on tephrochronology, Thorarinsson $(1951,1953)$ attempted to establish the age of the YLL. As ${ }^{14} \mathrm{C}$ dating was not available at the time, Thorarinsson relied on an estimated soil accumulation rate above the widespread and easily identified tephra layer H-3 that had been tentatively dated by palynological studies indicating an early Iron Age date (Tho- 
rarinsson 1951). Based on tephrochronology, Thorarinsson estimated the age of the YLL to be about 1800-2300 BP (Thorarinsson 1951).
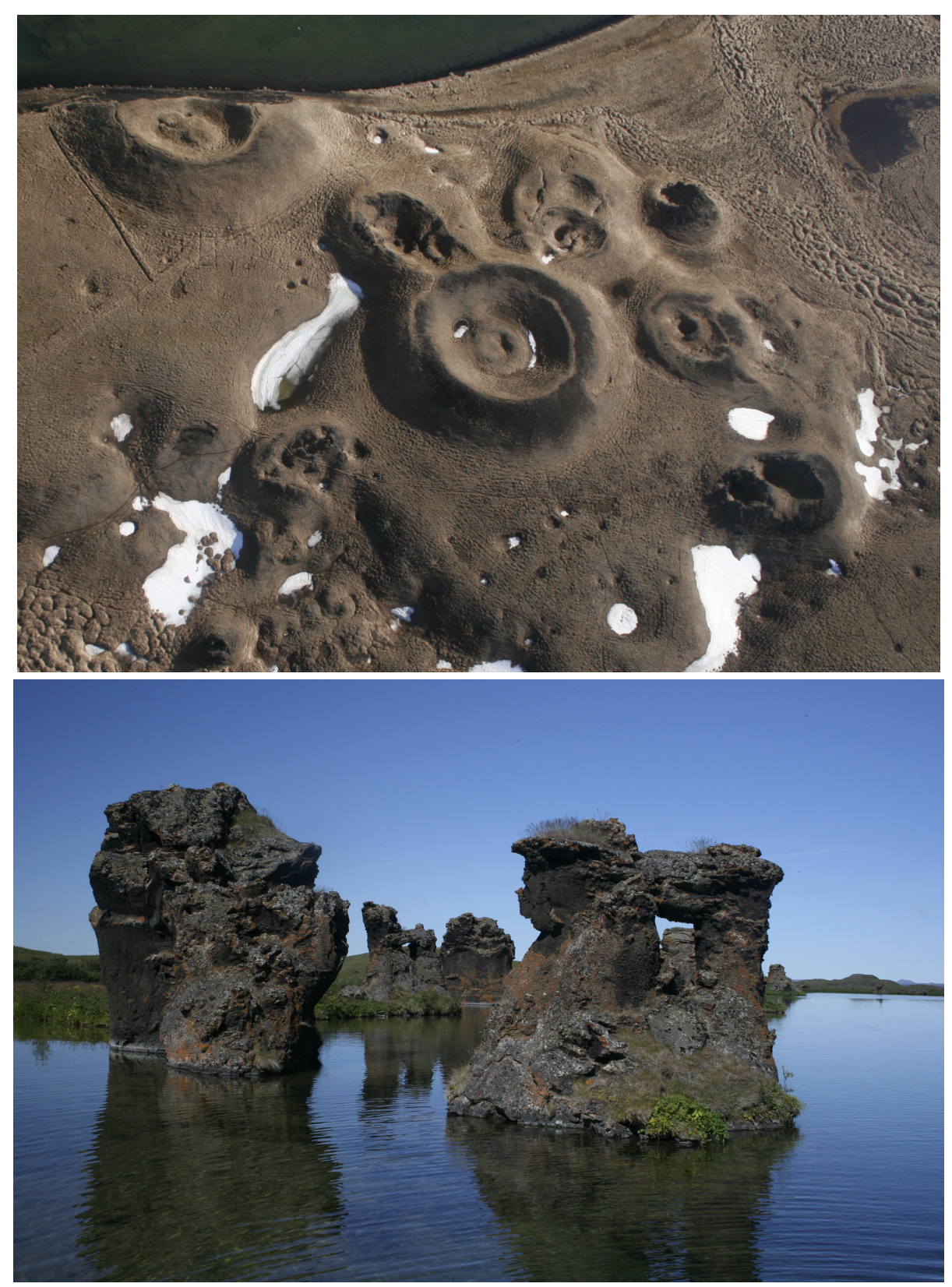

Figure 2 Upper: Aerial photograph of pseudocraters by Lake Mývatn. Diameter of pseudocrater in the center of the photo $\sim 50 \mathrm{~m}$. Lower: Lava pillars by the eastern shore of Lake Mývatn. Photo: Mývatn Research Station.

When the ${ }^{14} \mathrm{C}$ dating technique had been developed in 1949 (Arnold and Libby 1949; Libby 1952), Thorarinsson (1964) was able to put his age estimate for the YLL of 1800-2300 yr to the test. In 1951, 3 samples for ${ }^{14} \mathrm{C}$ analysis were collected, all from the same location at a construction site of the Laxá Hydropower Station, below the Laxárgljúfur Canyon (see Figure 3). 


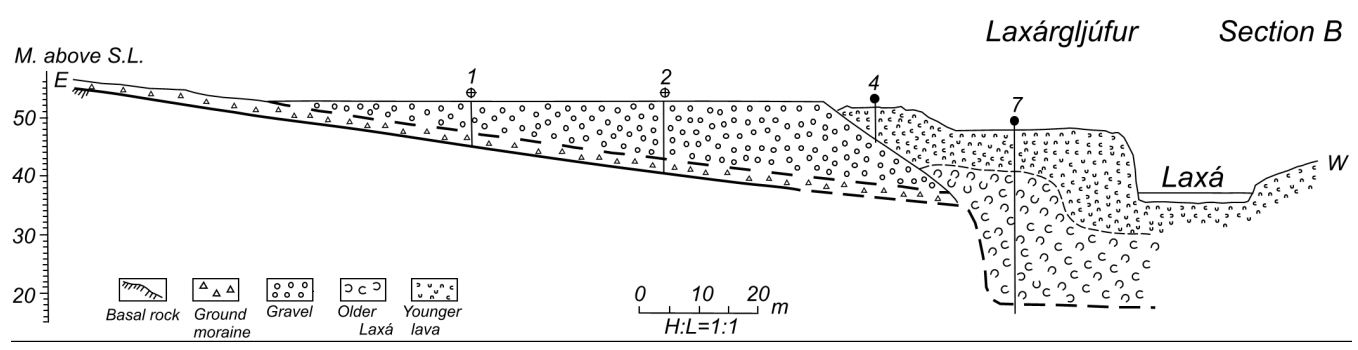

Figure 3 Geological cross-section through the valley below Laxárgljúfur (redrawn from Thorarinsson 1951)

The samples were of small woody plants that had been charred when overrun by the lava flow. The samples were sent to 3 different laboratories, the Geochronometric Laboratory of the Yale University, the Dating Laboratory of the University of Copenhagen, and the University of Manitoba in Winnipeg. The analyses yielded conventional (uncalibrated) ages of $1940 \pm 270{ }^{14} \mathrm{C}$ yr BP (Yale), $2110 \pm 140{ }^{14} \mathrm{C}$ yr BP (Copenhagen), and $1990 \pm 50{ }^{14} \mathrm{C}$ yr BP (Winnipeg) (Thorarinsson 1964).

Lake Mývatn has, since 1982, been the focus of paleolimnological research aimed at reconstructing and understanding the extreme fluctuations in the rich wildlife of this shallow, productive lake (e.g. Einarsson and Örnólfsdóttir 2004; Einarsson et al. 2004; Hauptfleisch et al. 2010). This requires reliable sediment chronology, including an age estimation of the lake. ${ }^{14} \mathrm{C}$ dating is usually applied to establish a chronology of lake sediments (Björck and Wohlfarth 2004), but in Lake Mývatn a spatially variable freshwater ${ }^{14} \mathrm{C}$ reservoir effect $\left(\sim 10,000{ }^{14} \mathrm{C}\right.$ yr) (Ascough et al. 2011) prevents ${ }^{14} \mathrm{C}$ dating of its sediments. A number of tephra layers in the sediment of Lake Mývatn enable the establishment of a chronological model for the microfossil records of the lake (Einarsson 1982; Einarsson et al. 1988, 1993; Hauptfleisch et al. 2010). An age estimation of the YLL by AMS ${ }^{14} \mathrm{C}$ dating would provide the maximum age of the sediment sequence deposited in Lake Mývatn and underpin the local tephrochronology by an independent state-of-the-art dating method. The opportunity came in 2007 when gravel mining at the edge of the YLL exposed the underlying strata, including a thin layer of wood charred by the lava. The results are reported here and discussed in the context of the earlier analyses.

\section{METHODS}

On 8 June 2007, a local farmer pointed the present authors to an active gravel pit where he had seen charred wood under the YLL. A thin layer of charcoal was found directly under the contact of the YLL with the buried paleosol in a section of the pit at Presthvammur in Aðaldalur (Figure 4). Inspection of the site revealed the remains of a Betula woodland, buried and preserved as a local layer by the YLL. The charcoal layer was sampled on 27 June 2007, following the guidelines for ${ }^{14} \mathrm{C}$ sampling described in Heinemeier (2007). The sample Presthvammur-01, containing a twig with a diameter of $0.5 \mathrm{~cm}$, was sent for accelerator mass spectrometry analysis (AMS) to the AMS C-14 Dating Centre at the Aarhus University in Denmark.

Following pretreatment of the sample with $1 \mathrm{M} \mathrm{HCl}$ and $1 \mathrm{M} \mathrm{NaOH}$, carbon was combusted to $\mathrm{CO}_{2}$, and partly transformed to graphite for $\mathrm{AMS}{ }^{14} \mathrm{C}$ dating with an $\mathrm{EN}$ tandem accelerator. The resulting ${ }^{14} \mathrm{C}$ age is reported in conventional ${ }^{14} \mathrm{C}$ yr $\mathrm{BP}$ in accordance with the international convention (Stuiver and Polach 1977) and has been corrected for fractionation in order to refer the result to be equivalent with the standard $\delta^{13} \mathrm{C}$ value of $-25 \%$ (wood). 

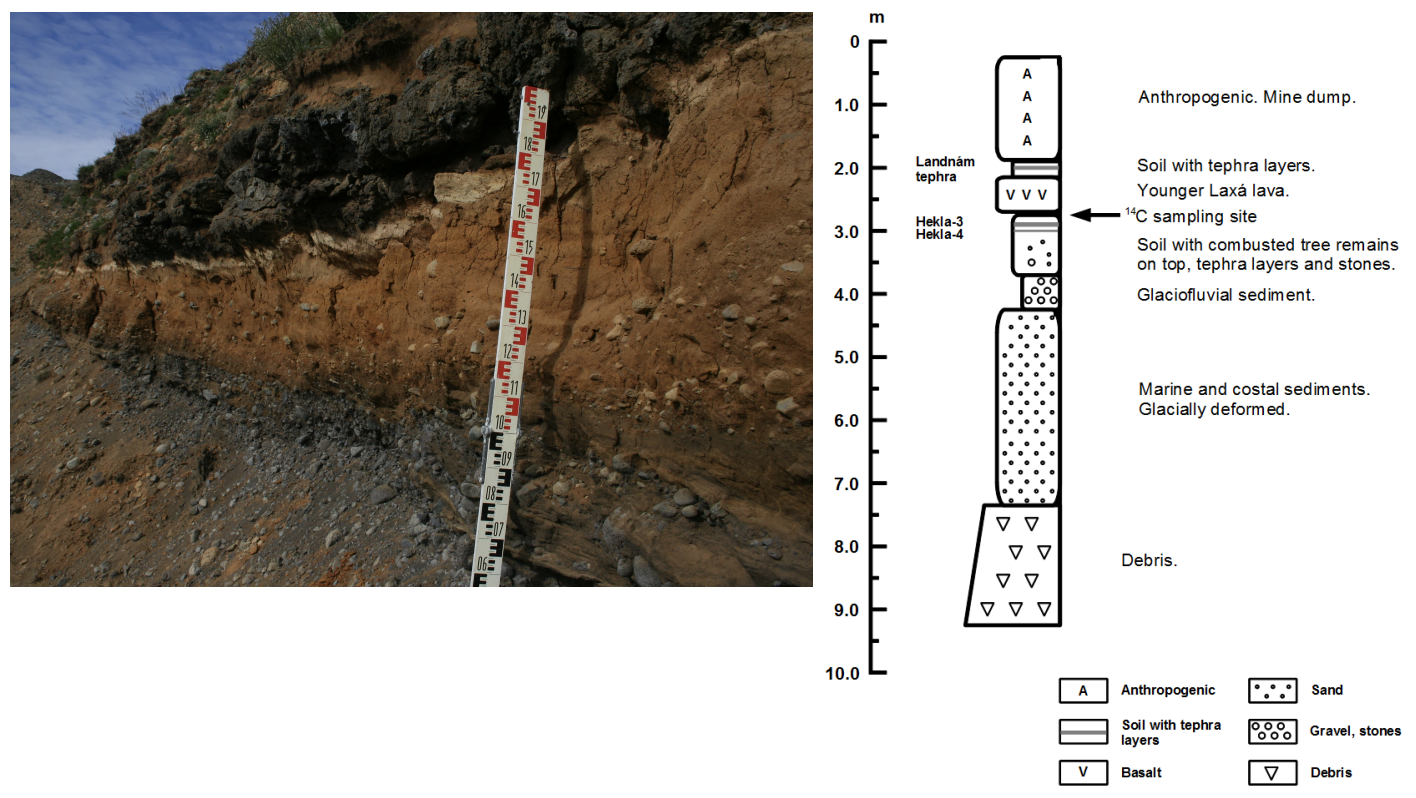

Figure 4 Left: Photograph of the sampling site at Presthvammur in Aðaldalur. The whitish layer seen under the Younger Laxá Lava is the Hekla-3 tephra (H-3). Photo: Mývatn Research Station; Right: Profile of the sampling site at Presthvammur in Aðaldalur.

Table $2{ }^{14} \mathrm{C}$ age of charcoal samples from northern Iceland in yr BP and in calibrated years BC/AD. All calibrated ages obtained using CALIB $(*=$ unknown).

\begin{tabular}{|c|c|c|c|c|c|c|c|}
\hline $\begin{array}{l}\text { Sample } \\
\text { (Lab nr) }\end{array}$ & $\begin{array}{l}{ }^{14} \mathrm{C} \text { age } \\
(\mathrm{BP})\end{array}$ & $\begin{array}{l}\text { Calibrated age } \\
1 \sigma \\
(\mathrm{cal} \mathrm{BC} / \mathrm{AD})\end{array}$ & $\begin{array}{l}\text { Rela- } \\
\text { tive } \\
\text { area }\end{array}$ & $\begin{array}{l}\text { Calibrated age } \\
2 \sigma \\
(\mathrm{cal} \mathrm{BC} / \mathrm{AD})\end{array}$ & $\begin{array}{l}\text { Rela- } \\
\text { tive } \\
\text { area }\end{array}$ & $\begin{array}{l}\delta^{13} \mathrm{C} \\
(\%)\end{array}$ & Reference \\
\hline \multirow{3}{*}{$\begin{array}{l}\text { Yale } \\
(\mathrm{Y}-87)\end{array}$} & \multirow[t]{3}{*}{$1940 \pm 270$} & \multirow{3}{*}{$\begin{array}{l}349-310 \text { cal BC } \\
209 \text { cal BC- } \\
\text { cal AD } 386\end{array}$} & 0.049 & $735-690 \mathrm{cal} \mathrm{BC}$ & 0.009 & $*$ & \multirow{3}{*}{$\begin{array}{l}\text { Thorarinsson } \\
1964\end{array}$} \\
\hline & & & 0.950 & $662-649 \mathrm{cal} \mathrm{BC}$ & 0.002 & $*$ & \\
\hline & & & & $\begin{array}{l}546 \text { cal BC- } \\
\text { cal AD } 646\end{array}$ & 0.989 & * & \\
\hline \multirow{4}{*}{$\begin{array}{l}\text { Copenhagen } \\
(\mathrm{K}-110)\end{array}$} & \multirow[t]{4}{*}{$2110 \pm 140$} & $358-281 \mathrm{cal} \mathrm{BC}$ & 0.211 & $482-467$ cal BC & 0.004 & * & \multirow{4}{*}{$\begin{array}{l}\text { Thorarinsson } \\
1964\end{array}$} \\
\hline & & 257-244 cal BC & 0.033 & $\begin{array}{l}415 \mathrm{cal} \mathrm{BC}- \\
\text { cal AD } 235\end{array}$ & 0.996 & * & \\
\hline & & $\begin{array}{l}235 \text { cal BC- } \\
\text { cal AD } 5\end{array}$ & & & & $*$ & \\
\hline & & cal AD 12-17 & & & & * & \\
\hline \multirow[t]{2}{*}{ Winnipeg $(*)$} & \multirow[t]{2}{*}{$1990 \pm 50$} & \multirow[t]{2}{*}{$\begin{array}{l}43 \mathrm{cal} \mathrm{BC}-\mathrm{cal} \\
\text { AD } 62\end{array}$} & \multirow[t]{2}{*}{1} & $151-140$ cal BC & 0.010 & $*$ & \multirow[t]{2}{*}{$\begin{array}{l}\text { Thorarinsson } \\
1964\end{array}$} \\
\hline & & & & $\begin{array}{l}111 \text { cal BC- } \\
\text { cal AD } 125\end{array}$ & 0.990 & $*$ & \\
\hline $\begin{array}{l}\text { Presthvam.-01 } \\
\text { (AAR: 12012) }\end{array}$ & $2170 \pm 38$ & $\begin{array}{l}354-290 \mathrm{cal} \mathrm{BC} \\
231-170 \mathrm{cal} \mathrm{BC}\end{array}$ & $\begin{array}{l}0.539 \\
0.461\end{array}$ & $365-110 \mathrm{cal} \mathrm{BC}$ & 1 & $-29.09 \pm 0.05$ & This study \\
\hline
\end{tabular}

Calibrated ages provided and calculated by the laboratory were obtained by means of the OxCal v 4.0 calibration program (Bronk Ramsey 2009) using the terrestrial calibration curve IntCal04 (Reimer et al. 2004). The probability method has been used to calculate the calibrated age ranges corresponding to $68.2 \%(1 \sigma)$ and $95.4 \%$ probability $(2 \sigma)$, with the probability of each range given in parentheses (indicating the probability that the true date belongs to the interval in question). 
The conventional ${ }^{14} \mathrm{C}$ ages of the charcoal samples from the Laxá Hydropower Station analyzed in 1951 and published by Thorarinsson (1964) have been converted to calibrated years by using the software CALIB 6.0.1, choosing the IntCal09 ${ }^{14} \mathrm{C}$ curve for non-marine ${ }^{14} \mathrm{C}$ samples from the Northern Hemisphere (Stuiver and Reimer 1993, 2005; Reimer et al. 2009). To avoid possible uncertainty due to the use of different conversion software, the AMS ${ }^{14} \mathrm{C}$ age from Presthvammur was converted to calibrated years by using CALIB 6.0.1. All calibrated ${ }^{14} \mathrm{C}$ ages discussed below are obtained from CALIB.

\section{RESULTS AND DISCUSSION}

AMS ${ }^{14} \mathrm{C}$ dating of the charcoal sample Presthvammur-01 beneath the YLL provided a calibrated ${ }^{14} \mathrm{C}$ age of $2170 \pm 38 \mathrm{cal}$ yr BP, corresponding to the age intervals $354-291$ and $232-171 \mathrm{cal} \mathrm{BC}(1 \sigma)$ (Figure 5, Table 2). The 2 age intervals are a result of the position of the sample Presthvammur close to a ${ }^{14} \mathrm{C}$ age plateau in the calibration curve (Figure 5; see also Stuiver and Pearson 1993: Figure $1 \mathrm{E})$, making the dating precision problematic. The AMS ${ }^{14} \mathrm{C}$ age is in good agreement with the age of 2300-1800 yr BP (BC 350-AD 150) estimated by Thorarinsson (1951) using tephrochronology.

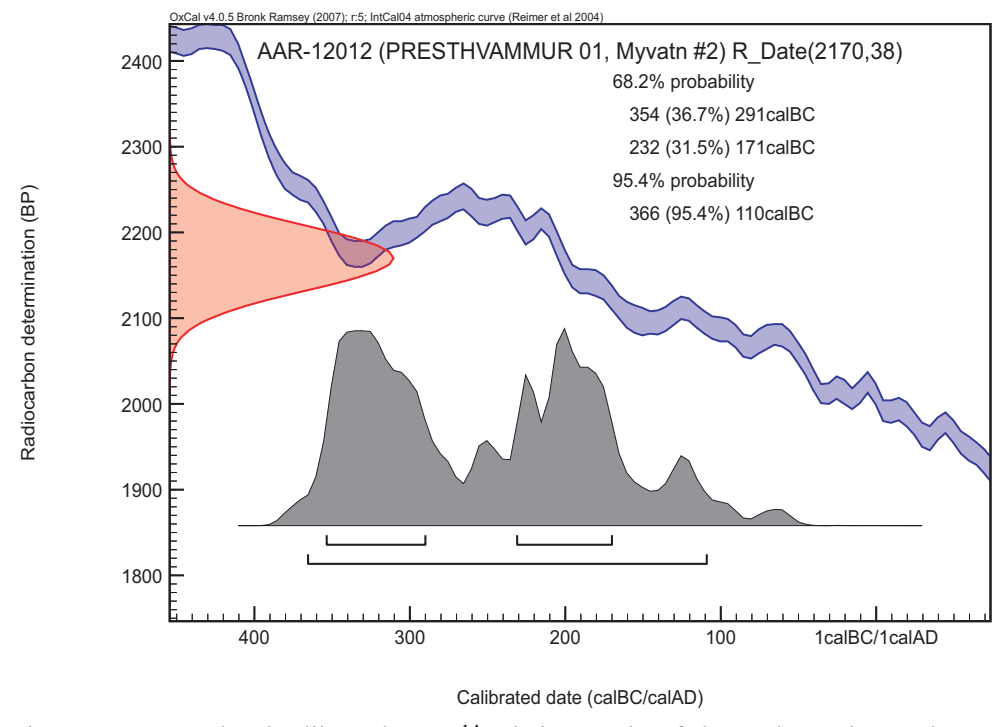

Figure 5 Corrected and calibrated AMS ${ }^{14} \mathrm{C}$ dating results of charcoal sample Presthvammur-01, collected in summer 2007. Data converted by OxCal v 4.0 (Bronk Ramsey 2009).

The ${ }^{14} \mathrm{C}$ ages of the charcoal sample from the Laxá Hydropower Station obtained in 1951 are only partly in agreement with the age intervals of the Presthvammur-01 sample (see Figure 6). The sample analyzed in Winnipeg yielded a conventional ${ }^{14} \mathrm{C}$ age of $1990 \pm 50{ }^{14} \mathrm{C} \mathrm{yr} \mathrm{BP}$, corresponding to a calendar age interval of $43 \mathrm{cal} \mathrm{BC-cal} \mathrm{AD} 62(1 \sigma)$. The $68.2 \%(1 \sigma)$ probability ranges of Presthvammur-01 and Winnipeg do not overlap, but at $2 \sigma$ a slight overlap occurs. The ${ }^{14} \mathrm{C}$ age of the sample analyzed in Copenhagen (K-110) is $2110 \pm 140{ }^{14} \mathrm{C}$ yr BP, which is equivalent to the age intervals $358-281 \mathrm{cal} B C$ and $235 \mathrm{cal} \mathrm{BC}-$ cal AD $5(1 \sigma)$. The older age interval of K-110 matches the older age interval obtained from the Presthvammur sample (354-291 cal BC), but the younger age interval of sample K-110 (235 cal BC-cal AD 5) is much larger than the younger interval of Presthvammur-01 (232-171 cal BC) (Figure 6). 


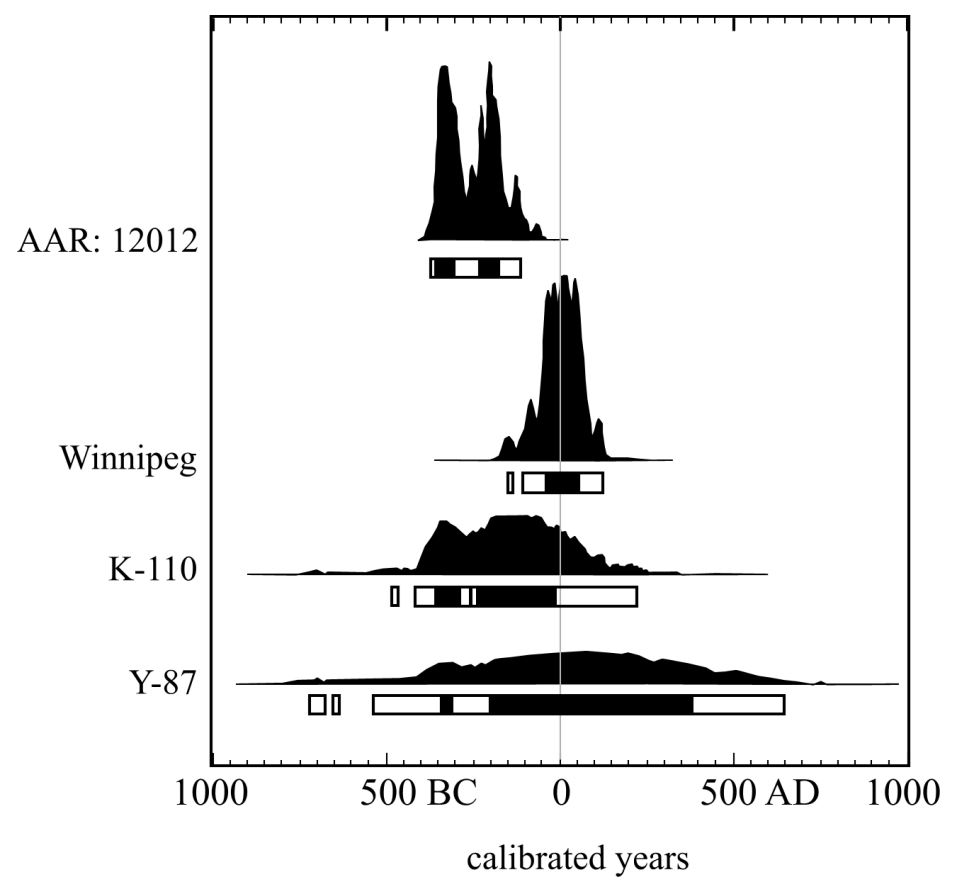

Figure $6{ }^{14} \mathrm{C}$ ages of charcoal samples Y-87, K-110, and Winnipeg, collected in summer 1951 (Thorarinsson 1964), compared with AAR: 12012. The black bars indicate the $68.2 \%(1 \sigma)$ and $95.4 \%(2 \sigma)$ probability ranges. All ${ }^{14} \mathrm{C}$ ages calibrated with CALIB 6.0.1 (Stuiver and Reimer 2005).

The charcoal sample analyzed at Yale (Y-87) yielded a conventional ${ }^{14} \mathrm{C}$ age of $1940 \pm 270{ }^{14} \mathrm{C}$ yr $\mathrm{BP}$, equivalent to an interval of $209 \mathrm{cal}$ BC-cal AD $386(1 \sigma)$. Sample Y-87 should be treated with caution due to the wide range of the estimated age interval.

We have a situation of 4 independent ${ }^{14} \mathrm{C}$ datings yielding slightly different results. They do all overlap at the $2 \sigma$ level, but the 2 samples with the smallest standard deviations (Winnipeg and Presthvammur) only slightly so. The question is if the samples can be ranked by reliability. The interpretation of charcoal ${ }^{14} \mathrm{C}$ ages can be affected by several factors (Bird 2007). Translocation of charcoal by bioturbation (Bird et al. 2002) in the soil profile of Presthvammur is unlikely, because inspection of the soil section at the sampling site yielded no signs of such processes. The sampled charcoal layer is situated on top of the paleosol, directly beneath the basaltic lava flow of the YLL. Further charcoal layers deeper in the paleosol were not observed. In situ contamination of the sampled charcoal by carbon sources from circulating soil solutions as described by Pietikäinen et al. (2000) seems low at Presthvammur due to the position of the birch forest remains on top of the paleosol profile and due to the contemporary covering of the charred wood and the underlying soil by the lava. Basaltic lava flow with a temperature of $1050-1200{ }^{\circ} \mathrm{C}$ (Kilburn 2000) can be assumed to have baked the soil beneath the charred birch forest and destroyed most of its organic content. To avoid the problem of inbuilt ages (Gavin 2001), a narrow twig with intact bark was chosen for the AMS ${ }^{14} \mathrm{C}$ analysis in Aarhus. Thus, the age of the sample Presthvammur-01 is unlikely to be affected by contamination of younger carbon or by inbuilt ages.

The age difference between the conventional and the AMS ${ }^{14} \mathrm{C}$ dates could possibly be explained by a lack of sampling strategy for the samples from the Laxá Hydropower Station, where the samples 
could have been taken from the innermost part of the charcoal tree branch. This could result in an age difference of perhaps $50 \mathrm{yr}$. A more extreme scenario is that the samples obtained in 1951 originated from older, coarse woody debris, burnt by the YLL to charcoal.

Another possible explanation for the age difference between the samples from the Laxá Hydropower Station and the sample from Presthvammur is the application of 2 different methods of ${ }^{14} \mathrm{C}$ dating at different stages of their development. The datings of the samples obtained in 1951 were done in the early years of the ${ }^{14} \mathrm{C}$ dating technique (Arnold and Libby 1949; Libby 1952) as a solid source counting technique based on the decay counting method of ${ }^{14} \mathrm{C}$ atoms. Recent conventional ${ }^{14} \mathrm{C}$ dating is done by gas proportional counting or liquid scintillation counting (Cook and van der Plicht 2007). The sample from Presthvammur was analyzed by AMS analysis (e.g. Nelson et al. 1977; Tuniz et al. 1998) based on the direct measurement of the proportion of ${ }^{14} \mathrm{C}$ to stable isotopes of carbon (Jull 2007).

Liedgren et al. (2007) studied the correspondence between conventional ${ }^{14} \mathrm{C}$ dates and AMS dates of charcoal samples from 12 prehistoric Sami settlement sites in northern Sweden. The study revealed a discrepancy between the existing chronology of the sites, based on conventional ${ }^{14} \mathrm{C}$ ages, and the new chronology, established by AMS ${ }^{14} \mathrm{C}$ dates. The authors suggest that the discrepancy is caused by methodological issues and that more accurate ${ }^{14} \mathrm{C}$ dates can be obtained by the AMS dating technique than the conventional ${ }^{14} \mathrm{C}$ dating (Liedgren et al. 2007). d'Ericco et al. (2011) compared conventional ${ }^{14} \mathrm{C}$ ages and AMS ${ }^{14} \mathrm{C}$ dates of archaeological cultures from sites in Europe and Russia. The evaluation of samples older than the Late Glacial Maximum (LGM) revealed that conventional ${ }^{14} \mathrm{C}$ ages are often younger and have a slightly greater error than the corresponding AMS ${ }^{14} \mathrm{C}$ ages from the identical archaeological culture. The authors report a smaller age difference between conventional and AMS data for samples younger than the LGM and interpret this as a result of a smaller sample size for AMS data from this time period (d'Ericco et al. 2011). It thus seems possible that the age differences of the charcoal samples from the Laxá Hydropower Station and Presthvammur most likely are due to a dating method at different levels of development.

Criteria for evaluating ${ }^{14} \mathrm{C}$ ages of archaeological samples have been established by Waterbolk (1971), Pettitt et al. (2003), and Graf (2009). The evaluation includes archaeological and chronometric criteria as well as scores from "very poor" to "very high" confidence. All authors consider the method of sample measurement and the availability of the laboratory reports as a criterion when evaluating ${ }^{14} \mathrm{C}$ ages. Following the criteria of Pettit et al. (2003) and Graf (2009), it has to be recognized that detailed information about the data from the Laxá Hydropower Station concerning sampling year, sampling procedure, sample measurement, and laboratory reporting are not available (Thorarinsson 1964). Furthermore, the samples from the Laxá Hydropower Station were measured in 1951 at a very early age of the ${ }^{14} \mathrm{C}$ dating technique.

The ${ }^{14} \mathrm{C}$ age of the Presthvammur sample was $\delta^{13} \mathrm{C}$-corrected for isotope fractionation as a part of the ${ }^{14} \mathrm{C}$ analysis $\left(\delta^{13} \mathrm{C}=-29.09 \pm 0.05 \%\right.$ ). The conventional ${ }^{14} \mathrm{C}$ ages could not be corrected for isotope fractionation because the method of radiometric measurement has to be known for choosing the exact $\delta^{13} \mathrm{C}$ correction (Stuiver and Reimer 2005). That deficit is probably biasing the sample ages from Laxá Hydropower Station, but is overridden by the fact that the year of measurement and laboratory procedures are unknown. Following the suggestions of Pettitt and Graf, all ages from the Laxá Hydropower Station are less reliable than the age of the sample of Presthvammur $(2170 \pm 38$ cal yr BP). A reliable age of the YLL should therefore be based only on the age of the Presthvammur sample. We suggest the age intervals of 354-290 and 231-170 cal BC for the Younger Laxá Lava, which are consistent with the time interval estimated by tephrochronology (350 BC-AD 150). 


\section{ACKNOWLEDGMENTS}

We are grateful to Hólmgrímur Kjartansson at Hraun in Aðaldalur, north Iceland, for his information about the charred wood in the open-pit mine at Presthvammur. We also thank Guðrún Larsen, University of Iceland, for information about the ${ }^{14} \mathrm{C}$ samples collected by Sigurður Thorarinsson at the Laxá Hydropower Station. Thanks are due to Hreggviður Norðdahl, University of Iceland, for his valuable comments on a draft of the manuscript. Finally, we would like to thank 2 anonymous reviewers who provided helpful comments and suggestions on a first version of this paper.

\section{REFERENCES}

Arnold JR, Libby WF. 1949. Age determinations by radiocarbon content: checks with samples of known ages. Science 110:678-80.

Ascough PL, Cook GT, Hastie H, Dunbar E, Church MJ, Einarsson Á, McGovern TH, Dugmore AJ. 2011. An Icelandic freshwater radiocarbon reservoir effect: implications for lacustrine ${ }^{14} \mathrm{C}$ chronologies. The Holocene 21(7):1073-80.

Bird MI. 2007. Radiocarbon dating. Charcoal. In: Elias SA, editor. Encyclopedia of Quaternary Science. Amsterdam: Elsevier. p 2950-8.

Bird MI, Turney CSM, Fifield LK, Jones R, Ayliffe LK, Palmer A, Cresswell R, Robertson S. 2002. Radiocarbon analysis of the early archaeological site of Nauwalabila I, Arnhem Land Australia: implications for sample suitability and stratigraphic integrity. Quaternary Science Reviews 21(8-9):1061-75.

Björck S, Wohlfarth B. $2004 .{ }^{14} \mathrm{C}$ chronostratigraphic techniques in paleolimnology. In: Last WM, Smol BF, editors. Tracking Environmental Change Using Lake Sediments. Volume 1. Basin Analysis, Coring, and Chronological Techniques. Dordrecht: Kluwer Academic Publishers. p 204-46.

Braitseva OA, Sulerzhitsky LD, Litasova SN, Meleketsev IV, Ponomareva VV. 1993. Radiocarbon dating and tephrochronology in Kamchatka. Radiocarbon 35(3):463-76.

Bronk Ramsey C. 2009. Bayesian analysis of radiocarbon dates. Radiocarbon 51(1):337-60.

Buchanan-Banks JM, Lockwood JP, Rubin M. 1989. Radiocarbon date for lava flows from northeast rift zone of Mauna Loa Volcano, Hilo 7 1⁄2' Quadrangle, Island of Hawaii. Radiocarbon 31(2):179-86.

Cook GT, van der Plicht J. 2007. Radiocarbon dating. Conventional method. In: Elias SA, editor. Encyclopedia of Quaternary Science. Amsterdam: Elsevier. p 2899-911.

d'Errico F, Banks W, Vanhaeren M, Laroulandie V, Langlais M. 2011. PACEA Geo-Referenced Radiocarbon Database. PaleoAnthropology 2011:1-12

Einarsson Á. 1982. The palaeolimnology of Lake Mývatn, northern Iceland: plant and animal microfossils in the sediment. Freshwater Biology 12:63-82.

Einarsson Á, Örnólfsdóttir EB. 2004. Long-term changes in benthic Cladocera populations in Lake Mývatn, Iceland. Aquatic Ecology 38:253-62.
Einarsson Á, Hafliðason H, Óskarsson H. 1988. Mývatn: Saga lífríkis og gjóskutímatal í Syðriflóa [Lake Mývatn: palaeolimnology and tephrochronology of the Syðriflói basin]. Mývatn Research Station, Report no. 4. Náttúruverndarráð, Reykjavík, Ísland. 96 p. In Icelandic with English summary.

Einarsson Á, Óskarsson H, Haflidason H. 1993. Stratigraphy of fossil pigments and Cladophora and its relationship with tephra deposition in Lake Mývatn. Journal of Paleolimnology 8:15-26.

Einarsson Á, Stefánsdóttir G, Jóhannesson H, Ólafsson JS, Gíslason GM, Wakana I, Gudbergsson G, Gardarsson A. 2004. The ecology of Lake Mývatn and River Laxá: variation in space and time. Aquatic Ecology 38: 317-48.

Einarsson S, Jóhannesson $\mathrm{H}$, Sveinbjörnsdóttir ÁE. 1991. Age of the Kapelluhraun and Hellnahraun lava flows, Reykjanes peninsula, Southwest Iceland. Jökull 41:61-80. In Icelandic with English summary.

Gavin DG. 2001. Estimation of inbuilt age of soil charcoal from fire history studies. Radiocarbon 43(1):2744.

Graf KE. 2009. "The good, the bad, and the ugly": evaluating the radiocarbon chronology of the middle and later Upper Paleolithic in the Enisei River valley, south-central Siberia. Journal of Archaeological Science 36(3):694-707.

Hauptfleisch U, Einarsson Á, Andersen TJ, Newton A, Gardarsson A. 2010. Matching thirty years of ecosystem monitoring with a high resolution microfossil record. Freshwater Biology. doi:10.1111/j.13652427.2010.02518.x

Heinemeier J. 2007. Prøveudtagning AMS Kulstoff-14 datering. AMS ${ }^{14} \mathrm{C}$ Dateringslaboratoriet, Institut for Fysik og Astronomi. Aarhus Universitet. $4 \mathrm{p}$. In Danish.

Hjartarson Á. 2011. The largest lavas of Iceland. Náttúrufraððingurinn 81:37-48. In Icelandic with English summary.

Jakobsson S. 1976. Aldur Grímsneshrauna. Náttúrufrceðingurinn 46:153-62. In Icelandic.

Jóhannesson H, Einarsson S. 1988. Age of the Ögmundarhraun lava flow and the Medieval tephra layer, Reykjanes peninsula, southwest Iceland. Jökull 38: 71-87. In Icelandic with English summary.

Jóhannesson H, Sæmundsson K. 1998. Jarðfræðikort af Íslandi. Berggrunnur. Mælikvarði 1:500.000. 2. útgáfa 
[Geological map of Iceland. Scale 1:500.000. 2nd edition]. Reykjavík: The Icelandic Institute for Natural History. In Icelandic.

Jóhannesson H, Sæmundsson K. 2009. Jarðfræðikort af Íslandi. Berggrunnur. Mælikvarði 1:600.000. 1. útgáfa [Geological map of Iceland. Scale 1:600.000. 1st edition]. Reykjavík: The Icelandic Institute for Natural History. In Icelandic.

Jónsson J. 1971. Hraun í nágrenni Reykjavíkur, 1. Leitahraun. Náttúrufrceðingurinn 41:49-63. In Icelandic.

Jónsson J. 1977. Reykjafellsgígir og Skarðsmýrarhraun á Hellisheiði. Náttúrufraðingurinn 47:17-26. In Icelandic.

Jónsson J. 1983. Eldgos á sögulegum tíma á Reykjanesskaga (Volcanic eruptions in historical time at the Reykjanes peninsula). Náttúrufraðingurinn 52:12739. In Icelandic with English summary.

Jull AJT. 2007. Radiocarbon dating. AMS method. In: Elias SA, editor. Encyclopedia of Quaternary Science. Amsterdam: Elsevier. p 2911-8.

Kilburn CRJ. 2000. Lava flows and flow fields. In: Sigurdsson H, Houghton BF, editors. Encyclopedia of Volcanoes. London: Academic Press. p 291-305.

Kjartansson G. 1964. ${ }^{14} \mathrm{C}$ ages of some postglacial lavas in South Iceland. Náttúrufrceðingurinn 34:101-13. In Icelandic with English summary.

Kjartansson G. 1966. Nokkrar nýjar C14-aldursákvarðanir. Náttúrufraeðingurinn 36:126-41. In Icelandic.

Kjartansson G. 1973. The age of the Búrfell lava at Hafnarfjörður. Náttúrufrceðingurinn 42:159-83. In Icelandic with English summary.

Libby WF. 1952. Radiocarbon Dating. Chicago: University of Chicago Press. 124 p.

Liedgren LG, Bergman IM, Hörnberg G, Zackrisson O, Hellberg E, Östlund L, DeLuca TH. 2007. Radiocarbon dating of prehistoric hearths in alpine northern Sweden: problems and possibilities. Journal of Archaeological Science 34(8):1276-88.

Madeira J, Monge Soares AM, da Silveira AB, Serralheiro A. 1995. Radiocarbon dating recent volcanic activity on Faial Island (Azores). Radiocarbon 37(2): $139-47$.

Nelson DE, Korteling RG, Stott WR. 1977. Carbon-14: direct detection at natural concentrations. Science 198(4316):507-8

Okuno M, Nakamura T, Kobayashi T. 1998. AMS ${ }^{14} \mathrm{C}$ dating of historic eruptions of the Kirishima, Sakurajima and Kaimondake volcanoes, Southern Kyushu, Japan. Radiocarbon 40(2):825-32.

Pettitt PB, Davies W, Gamble CS, Richards MB. 2003. Palaeolithic radiocarbon chronology: quantifying our confidence beyond two half-times. Journal of Archaeological Science 30(12):1685-93.

Pietikäinen J, Kiikkilä O, Fritze H. 2000. Charcoal as a habitat for microbes and its effect on the microbial community of the underlying humus. Oikos 89:231-

Reimer PJ, Baillie MGL, Bard E, Bayliss A, Beck JW,
Bertrand CJH, Blackwell PG, Buck CE, Burr GS, Cutler KB, Damon PE, Edwards RL, Fairbanks RG, Friedrich M, Guilderson TP, Hogg AG, Hughen KA, Kromer B, McCormac G, Manning S, Bronk Ramsey C, Reimer RW, Remmele S, Southon JR, Stuiver M, Talamo S, Taylor FW, van der Plicht J, Weyhenmeyer CE. 2004. IntCal04 terrestrial radiocarbon age calibration, 0-26 cal kyr BP. Radiocarbon 46(3):1029-58.

Reimer PJ, Baillie MGL, Bard E, Bayliss A, Beck JW, Blackwell PG, Bronk Ramsey C, Buck CE, Burr GS, Edwards RL, Friedrich M, Grootes PM, Guilderson TP, Hajdas I, Heaton TJ, Hogg AG, Hughen KA, Kaiser KF, Kromer B, McCormac FG, Manning SW, Reimer RW, Richards DA, Southon JR, Talamo S, Turney CSM, van der Plicht J, Weyhenmeyer CE. 2009. IntCal09 and Marine09 radiocarbon age calibration curves, $0-50,000$ years cal BP. Radiocarbon 51(4): 1111-50.

Sæmundsson K. 1962. Das Alter der Nesja-lava (SW Island). Neues Jahrbuch für Geologie und Paläontologie 12:650. In German.

Sæmundsson K. 1966. Zwei neue C14-Datierungen isländischer Vulkanausbrüche. Eiszeitalter und Gegenwart 17:85-6. In German.

Sæmundsson K. 1991. Jarðfræði Kröflukerfisins (The geology of the Krafla system). In: Gardarsson A, Einarsson Á, editors. Náttúra Mývatns. Reykjavík: Hið íslenska náttúrufræðifélag. In Icelandic. p 24-95.

Sinton J, Grönvold K, Sæmundsson K. 2005. Postglacial eruptive history of the Western Volcanic Zone, Iceland. Geochemistry, Geophysics, Geosystems 6: Q12009, doi:10.1029/2005GC001021.

Stuiver M, Polach HA. 1977. Discussion: reporting of ${ }^{14} \mathrm{C}$ data. Radiocarbon 19(3):355-63.

Stuiver M, Pearson GW. 1993. High-precision bidecadal calibration of the radiocarbon time scale, AD 1950$500 \mathrm{BC}$ and 2500-6000 BC. Radiocarbon 35(1):1-23.

Stuiver M, Reimer PJ. 1993. Extended ${ }^{14} \mathrm{C}$ data base and revised CALIB $3.0{ }^{14} \mathrm{C}$ age calibration program. $R a$ diocarbon 35(1):215-30.

Stuiver M, Reimer PJ. 2005. CALIB 5.0 [WWW program and documentation]. URL: http:// calib.qub.ac.uk/calib/.

Thorarinsson S. 1951. Laxárgljúfur and Laxárhraun. A tephrochronological study. Geografiske Annaler Stockholm H. 1-2:1-89.

Thorarinsson S. 1953. The crater groups in Iceland. Bulletin of Volcanology XIV:3-44.

Thorarinsson S. 1964. Aldur öskulaga [The age of tephra layers]. Náttúrufrceðingurinn 34:113-26. In Icelandic with English summary.

Thorarinsson S. 1979. The postglacial history of the Mývatn area. Oikos 32:17-28.

Tuniz C, Bird JR, Fink D, Herzog GF. 1998. Accelerator Mass Spectrometry: Ultrasensitive Analysis for Global Science. Boca Raton: CRC Press. 400 p.

Waterbolk TH. 1971. Working with radiocarbon dates. Proceedings of the Prehistoric Society 37:15-33. 